IRA-International Journal of Education \& Multidisciplinary Studies

ISSN 2455-2526; Vol.04, Issue 01 (2016)

Institute of Research Advances

http://research-advances.org/index.php/IJEMS

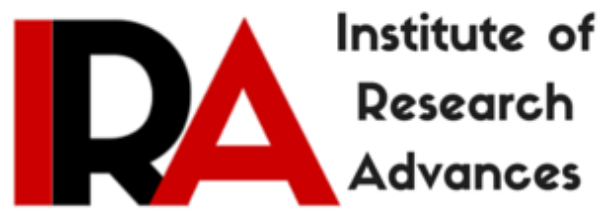

\title{
A Review of India's Foreign Trade with reference to Post RBI Road MAP 2005 and Financing by Foreign Banks (FB) during the period $2003-2013$
}

\author{
Mr. Ashok Vasant Edurkar \\ Researcher (B. Tech. MBA) \\ Management Consultant, Stork International GmbH, Vienna, Austria.
}

DOI: http://dx.doi.org/10.21013/jems.v4.n1.p3

\section{How to cite this paper:}

Edurkar, A. (2016). A Review of India's Foreign Trade with reference to Post RBI Road MAP 2005 and Financing by Foreign Banks (FB) during the period 2003 -2013. IRA International Journal of Education and Multidisciplinary Studies (ISSN 2455-2526), 4(1). doi:http://dx.doi.org/10.21013/jems.v4.n1.p3

(C) Institute of Research Advances

\section{(cc) EY-NC}

This works is licensed under a Creative Commons Attribution-Non Commercial 4.0 International License subject to proper citation to the publication source of the work.

Disclaimer: The scholarly papers as reviewed and published by the Institute of Research Advances (IRA) are the views and opinions of their respective authors and are not the views or opinions of the IRA. The IRA disclaims of any harm or loss caused due to the published content to any party. 
1 Introduction: - Transactions related to global trade flows have significantly improved at present, on account of the internationalization and highly developed e-commerce. Exports and imports opportunities have substantially increased so also risk associated with international trade has reached a high level. Along with issues related to languages used for communication involved in international marketing, drafting of letter of intent / purchase order, drafting of letter of credit, financing during execution of purchase order, pre and post shipment inspection and finally negotiation of bank documents for collection of payments, the international trade was always been quite risky. This risk is because of the fact that exporters and importers are from different countries, separated not only by physical distance but by socio political conditions. Actual trade flows determines quantum of foreign trade. Foreign trade divided by GDP is a good measure of improvement or growth in foreign trade. (Harrison 1996). There is a positive relationship between Foreign Trade well supported by domestic as well as foreign banks and economic growth (Edwards 1992).Mixed results are obtained during the study related to explanation of the causal relationship between the degree of openness of the economy and economic growth. This paper takes a review of India's Foreign Trade with reference to post RBI Road Map 2005 and financing by Foreign Banks (FB) during the period 2003-2013.

2 India's exports, imports and foreign trade: - Table 2.1 (figures in INR million)

\begin{tabular}{|l|l|l|l|}
\hline Year & Exports & Imports & Foreign Trade \\
\hline $2003-04$ & 2933670 & 3591080 & 6524750 \\
\hline $2004-05$ & 3753400 & 5010650 & 8764050 \\
\hline $2005-06$ & 4564180 & 6604090 & 11168270 \\
\hline $2006-07$ & 5717790 & 8405060 & 14122850 \\
\hline $2007-08$ & 6558640 & 10123120 & 16681760 \\
\hline $2008-09$ & 8407550 & 13744360 & 22151910 \\
\hline $2009-10$ & 8455340 & 13637360 & 22092700 \\
\hline $2010-11$ & 11429220 & 16834670 & 28263890 \\
\hline $2011-12$ & 14659590 & 23454630 & 38114220 \\
\hline $2012-13$ & 16343190 & 26691620 & 43034810 \\
\hline
\end{tabular}

Source: DGCIS's Report-2013) Table 2.1 indicates that over the 10 year's period the foreign trade growth is $559.56 \%$. $(((43034810-6524750) / 6524750) * 100)$

\section{Graph 1:- India's exports, imports and foreign trade}

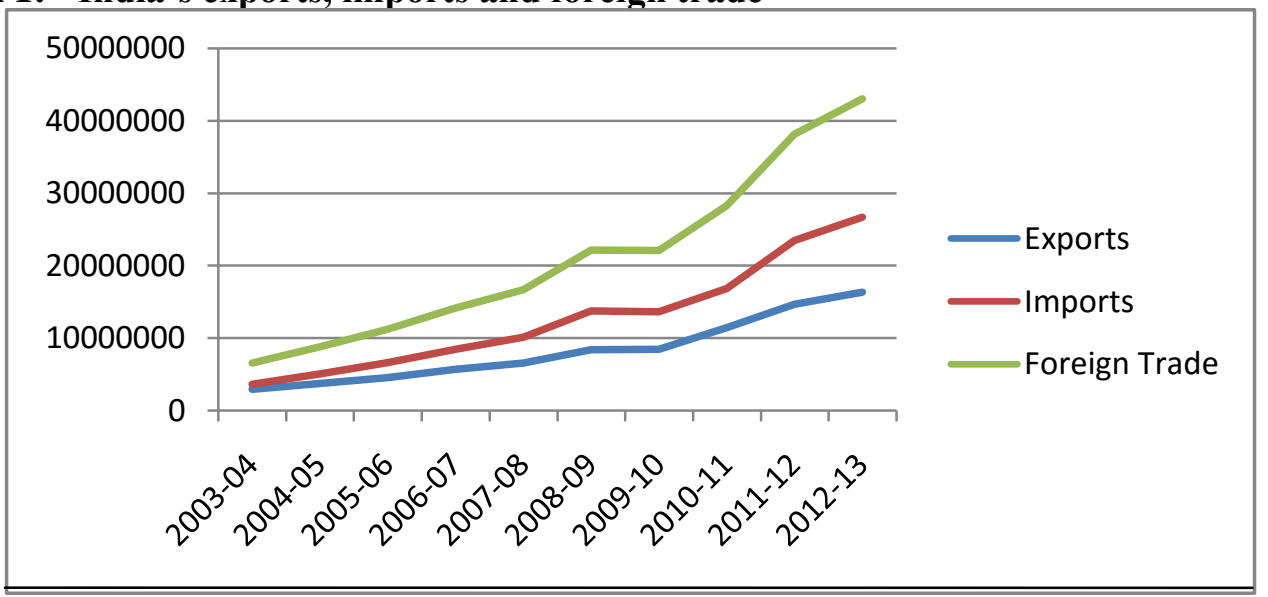

Source: DGCIS's Report-2013) Graph 1 indicates that exports, imports and foreign trade are increasing with positive slope during the period 2003-04 to 2012-13.

2.1 Year wise Percentage Growth: - During the period 2003-04 to 2012-13 year wise percentage growth of foreign trade of India, was not uniform. Year wise percentage growth of exports/imports/foreign trade was as follows:- 
Table 2.1.1:- Year wise \% Growth of Exports, Imports and Foreign Trade

\begin{tabular}{|l|l|l|l|}
\hline Year & $\begin{array}{l}\text { \%Growth of } \\
\text { Exports }\end{array}$ & $\begin{array}{l}\text { \%Growth of } \\
\text { Imports }\end{array}$ & $\begin{array}{l}\text { \%Growth of } \\
\text { Foreign Trade }\end{array}$ \\
\hline $2003-04$ & 14.98 & 20.83 & 18.13 \\
\hline $2004-05$ & 27.94 & 39.53 & 34.32 \\
\hline $2005-06$ & 21.60 & 31.80 & 27.43 \\
\hline $2006-07$ & 25.28 & 27.27 & 26.46 \\
\hline $2007-08$ & 14.71 & 20.44 & 18.12 \\
\hline $2008-09$ & 28.19 & 35.77 & 32.79 \\
\hline $2009-10$ & 0.57 & -0.78 & -0.27 \\
\hline $2010-11$ & 35.17 & 23.45 & 27.93 \\
\hline $2011-12$ & 28.26 & 39.32 & 34.85 \\
\hline $2012-13$ & 11.48 & 13.80 & 12.91 \\
\hline
\end{tabular}

Source: DGCIS's Report-2013)

Table 2.1.1 indicates that during the period 2003-04 to 2012-13, spurts in growth observed. For the year 2009-10 the foreign trade growth was negative $(-0.27 \%)$

\section{Graph 2:- Year wise \% Growth of Exports / Imports/ Foreign Trade}

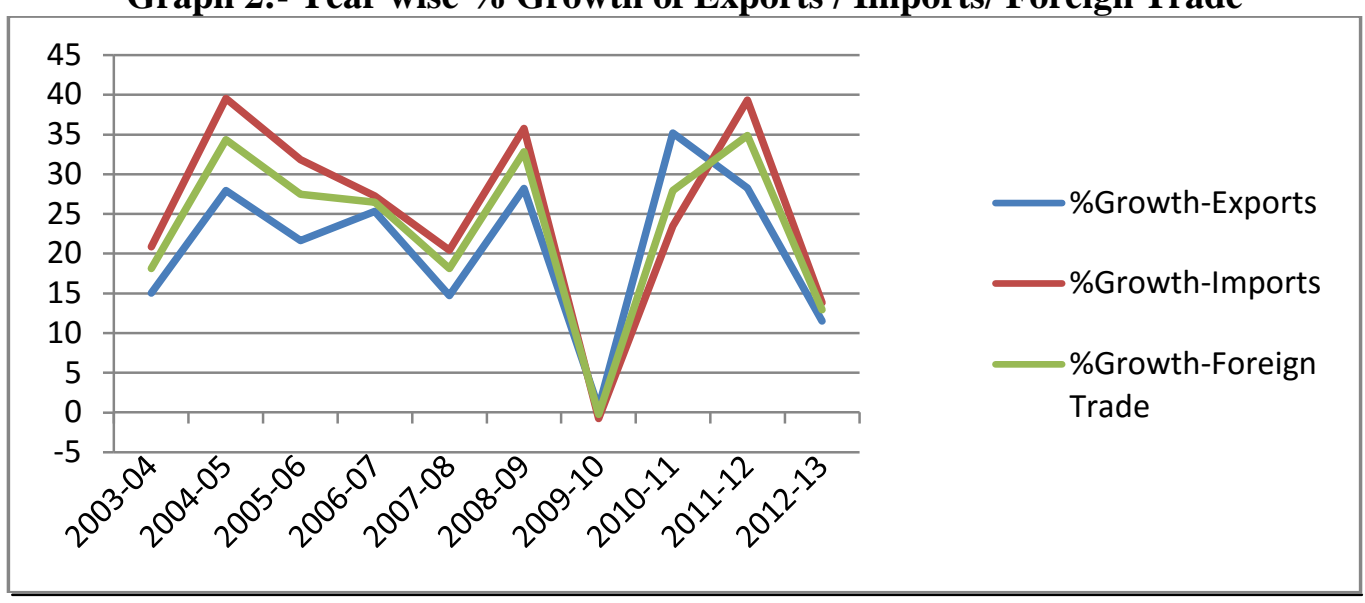

Source: DGCIS’s Report-2013)

Graph 2 indicates that during the period 2003-04 to 2012-13, the value of slope of graph lines for exports, imports, foreign trade was not uniform. The slope value went on changing from positive to negative with spurts during the above period.

2.2 Percentage Trade Deficit (TD): - Trade deficit is important from the point view of monitoring balance of payment. High value of trade deficit created stress on Indian economy during the period 2003-04 to 2012-13.

Table 2.2.1:- Percentage Trade Deficit (TD)

\begin{tabular}{|l|l|l|l|l|l|l|l|l|l|l|}
\hline Year & $\begin{array}{l}2003- \\
04\end{array}$ & $\begin{array}{l}2004- \\
05\end{array}$ & $\begin{array}{l}2005- \\
06\end{array}$ & $\begin{array}{l}2006- \\
07\end{array}$ & $\begin{array}{l}2007- \\
08\end{array}$ & $\begin{array}{l}2008- \\
09\end{array}$ & $\begin{array}{l}2009- \\
10\end{array}$ & $\begin{array}{l}2010- \\
11\end{array}$ & $\begin{array}{l}2011- \\
12\end{array}$ & $\begin{array}{l}2012- \\
13\end{array}$ \\
\hline $\begin{array}{l}\% \\
\text { TD }\end{array}$ & 22.41 & 33.50 & 44.69 & 47.00 & 54.35 & 63.48 & 61.29 & 47.30 & 60.00 & 63.32 \\
\hline
\end{tabular}

Source: DGCIS's Report-2013)

Table 2.1.1 indicates that during the period 2003-04 to 2012-13, the percentage trade deficit went on increasing i.e. for every year the gap between imports and exports went on increasing. 
Graph 3:-Percentage Trade Deficit (TD)

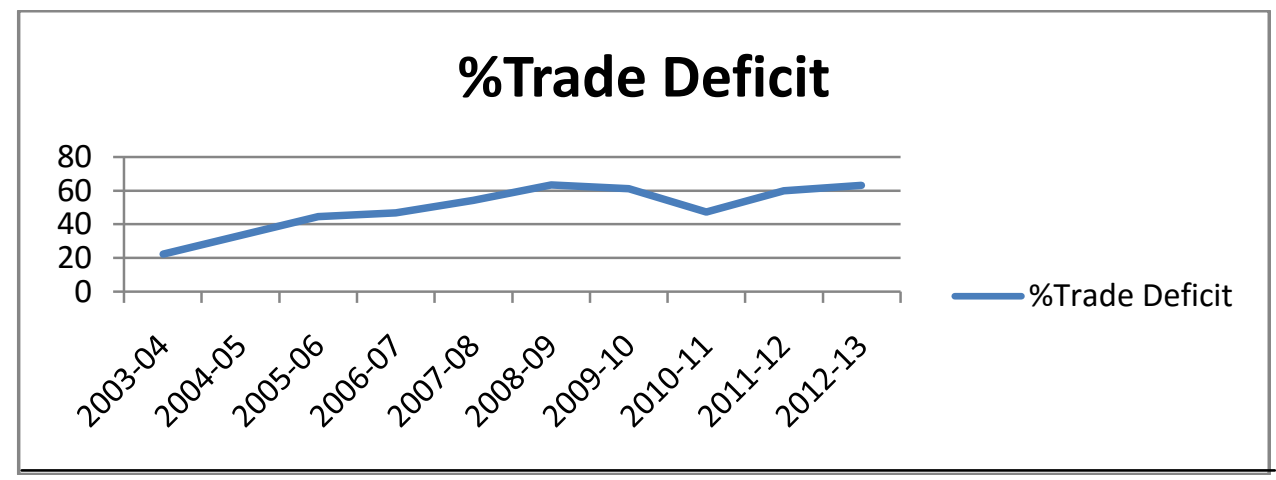

Source: DGCIS's Report-2013)

Graph 3 indicates that during the period 2003-04 to 2012-13, the value of slope of the graph for percentage trade deficit was not uniform. It went on changing from positive to negative with spurts.

2.3 India's exports: - In the financial year, 2013-14, India's exports were US\$ 312.61 billion. Here, the annual growth observed was $4.06 \%$ whereas in the earlier year there was a negative growth rate of $1.82 \%$. During the period 2004-05 to 2013-14, Compound Annual Growth Rate (CAGR) was 15.79\% in spite of setback faced by Indian export sector on account of global slowdown. USA retained the position of favorable destination with a share of 12.4\% in 2013-14 in India's exports although there is a gradual shift in export direction, i.e. moving away from advanced economies to developing economies.

Table 2.3.1:- India's Top Ten Exporters (Based on \% of Exports)

\begin{tabular}{|l|l|l|l|}
\hline Particulars & $\begin{array}{l}\text { Total Sales } \\
\text { (FY 20011-12) }\end{array}$ & \% Of Exports & Export Sales \\
\hline Oracle Financial Services Software & $2,3605.1$ & 96.02 & $2,2665.6$ \\
\hline Opto Circuits India & 6032 & 94.92 & 5725.6 \\
\hline Infosys & 25,3850 & 94.38 & $23,9583.6$ \\
\hline TCS & 29,2750 & 91.08 & $26,6636.7$ \\
\hline Divi's Lab & $1,3097.1$ & 90.36 & $1,1834.5$ \\
\hline Rajesh Exports & $20,5337.6$ & 85.61 & $17,5789.5$ \\
\hline Tech Mahindra & 4,9655 & 84.75 & $4,2082.6$ \\
\hline Aban Offshore & $1,1907.4$ & 84.39 & $1,0048.7$ \\
\hline Sesa Goa & $8,2219.4$ & 76.39 & $6,2807.4$ \\
\hline Dr. Reddy's Lab & 5,1885 & 72.23 & $3,7476.5$ \\
\hline
\end{tabular}

Sourse: - Dalal Street Investment Journal dated 25/5/2012, Values in INR Million

Graph 4 India's Export Destinations

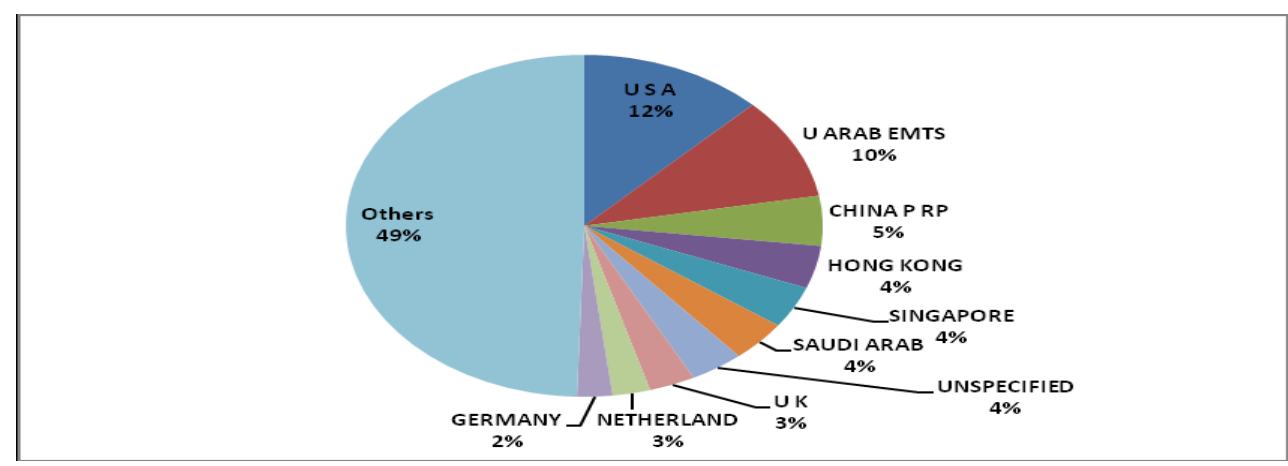

Source: DGCIS’s Report-2013) 
Graph 4 indicates that both USA and UAE are India's major export destinations having a percentage share of 12 and 10 respectively. Other countries are at below 5\% level.

\subsection{Limiting factors in growth of India's Exports are as under: -}

2.4.1 Products becoming uncompetitive on both quality and price front

2.4.2 Possible rejection of products on environmental issues.

2.4.3 Global trade not increasing a per expectations

2.4.4 Frequent up and down in values of various foreign currencies of foreign trade partner countries $\&$ deliberate devaluation of currency by competing country.

2.4.5 Block heads created by importing countries in the form of tariff and tariff measures.

Experts point out that India lacks versatility in production and it does not quickly response to international demand and supply variations as it has in built limitations. Absence of full achievement or utilization of SEZs facilities, uneconomical costs involved in export transactions, financing export trade at more costs and inadequate infrastructure facilities are critical issues for India's exports at domestic level.

2.5 India's Imports: - During the year 2013-14 India's imports amounted to US\$ 450.07 billion whereas this figure was US\$ 490.74 billion in 2012-13 year. Thus imports were contracted by $8.29 \%$ in 2013-14 resulting a negative growth. Item wise imports figures are as follows:-

Table 2.5.1: Percentage Growth in Imports

\begin{tabular}{|l|l|l|l|l|}
\hline Item & $2013-14$ & $2012-13$ & Difference & \% Growth \\
\hline Oil & 167.62 & 164.04 & 3.58 & 2.2 \\
\hline Non-Oil & 283.32 & 326.70 & -43.38 & -13.3 \\
\hline
\end{tabular}

Source: DGCIS's Report-2013)

Table 2.5.1 indicates that for Oil imports \% growth is positive whereas for non-oil imports \% growth is negative.

2.6 Drop in Trade deficit (TD): - During the year 2013-14 India's was able to lower the trade deficit from US\$ 190.34 to US\$ 137.46 compared to the year 2012-13. This was possible because of decrease in imports from US\$ 490.7 to US\$ 450.1 and with a little growth in exports yielding a significant contribution for monitoring current account deficit (CAD).

2.7 India's Foreign Trade: - During the year 2013-14, India's foreign trade amounted to US\$ 760 billion. Graph 5: India's Foreign Trade

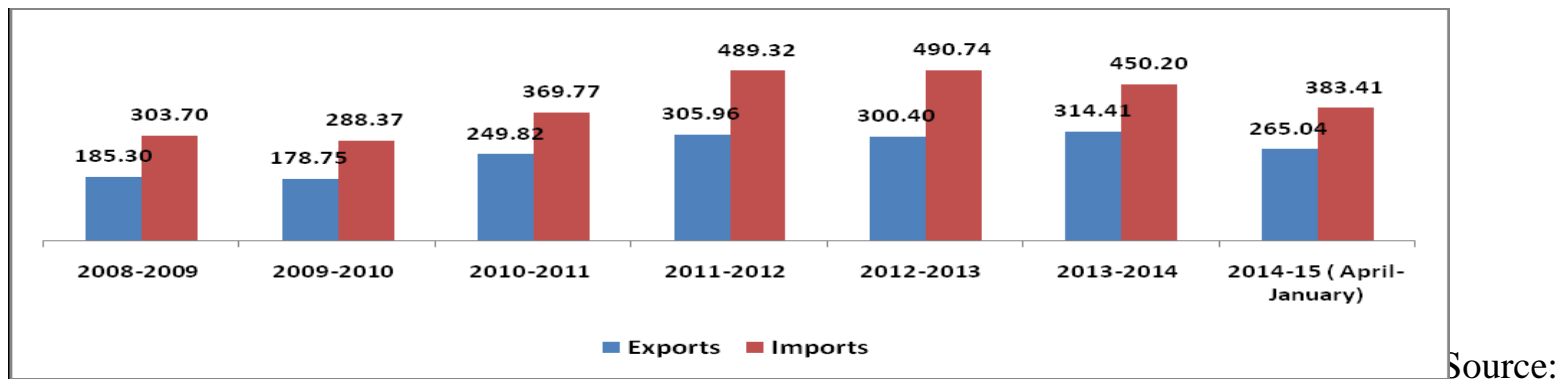

DGCIS's Report-2013)

Graph 5 indicates that although India's foreign trade is increasing year by year, its trade deficit is also increasing due to large gap between imports and exports.

2.8 Reasons for Trade Deficit: - For important products like crude oil, natural gas, coal, pulses, edible oils, fertilizers and electronics India has no choice other than to depend on imports which results in increasing level of trade deficit. During the year 2014-15, with a fall in oil prices, India has monitored trade deficit effectively. 
2.9 WTO's Appraisal for India: - Contribution to world trade and position in world trade:-

Table 2.9.1: India's Share in Global Trade (Source: WTO's World Trade Report, 2014)

\begin{tabular}{|l|l|l|l|}
\hline $\begin{array}{l}\text { India's Exports of } \\
\text { Merchandise Value }\end{array}$ & Share/Rank & $\begin{array}{l}\text { India's Imports of } \\
\text { Merchandise Value }\end{array}$ & Share/Rank \\
\hline 313 & $1.7 \%(19$ th $)$ & 466 & $2.5 \%$ (12th ) \\
\hline $\begin{array}{l}\text { India's Exports of } \\
\begin{array}{l}\text { Commercial services } \\
\text { Value }\end{array}\end{array}$ & Share/Rank & $\begin{array}{l}\text { India's Imports of } \\
\text { Commercial services } \\
\text { Value }\end{array}$ & Share/Rank \\
151 & $3.2 \%$ (6th) & 125 & $2.8 \%$ (9th) \\
\hline
\end{tabular}

Source: DGCIS's Report-2013)

Table 2.9.1 indicates that in view of world foreign trade India's role is substantially significant.

2.10 Dynamic Scenario: - International economy is a dynamic economy. International marketing scenario is always changing with changes in political \& economical changes related to various countries involved in foreign trade. After 2008-09, global slowdown, USA \& European economies were slowed to some extent. However, with necessary fiscal measures these economies were put on the growth path which is a positive signal for the expected growth in the international trade. However the recent slowdown in China \& Europe will have some adverse regional effects. India's foreign trade is affected due to the above mentioned contraction of European \& Chinese economy as both are leading contributors to India's foreign trade basket.

2.11 Critical Steps for Addition of High Value in an International Product: - For effective international trade these steps are very important. Today's foreign trade involves more than one country, contributing raw or semi processed products \& services which are further processed using fully developed production \& services set up for the outcome of a high value added final product. At each stage of such critical step value addition process occurs to benefit the concerned processing unit. India is also a contributor to aforesaid critical steps for international value addition covering areas like production of Jewelry, Electronics \& allied products, chemicals, minerals, financial \& banking services, information technology products \& services, with the help of off shore support units and sourcing necessary material plus manpower from nearby countries. The share of imported inputs and intermediate goods in exports is higher in mining, textiles, machinery, and services sectors such as distribution, transport and telecom. In general, inadequate infrastructure, sub-optimal connectivity with global transport networks, low transport capabilities and complicated administrative requirements that cause long delays at ports and customs, are some of the serious obstacles to participation by Indian producers \& service providers in such areas. In all these areas, they are at a disadvantage as compared to producers \& service providers in the ASEAN countries and East Asia. For India to successfully integrate into Critical Steps for Addition of High Value in an International Product either regional or global India needs to strengthen trade-related physical infrastructure, implement an appropriate regulatory regime for transport services, improve efficiency and predictability in border procedures, undertake policy reforms in logistics services markets (logistics quality and competence, tracing and tracking etc.) and reduce coordination failures, especially those of public agencies active in border control - facilitate imports of parts and components by, inter alia, optimizing tariff policy, enhance design capabilities within the country and address issues relating to our rules of origin. Also required is an enabling environment for industry to be able to both scale up and scale down their operations in response to demand.

2.12 Financing by Foreign Banks (FB): -Foreign Trade (FT) in the modern economy is a complex system of value creation and transformation, wherein Foreign Trade policies of various countries, Foreign Trade players and foreign banks play significant role. The financial markets of various countries and FBs project it to new heights of efficiency and funding accessibility for further value creation. Foreign Trade is to benefit from FBs financial system implications, however, at the same 
time; it became dependent on it on account of FBs' market oriented credit policies. Over the past decade, FBs have become much more important in domestic financial intermediation, heightening the need to understand their models. FBs have helped in bettering the technology used in the financing sector. The first Automated Teller Machine (ATM) in India was brought up by Hong Kong and Shanghai Banking Corporation Ltd (HSBC) and from then on FBs have contributed to the latest financing practices. FBs have become more \& more efficient today and their Return on Assets has clearly shown a positive trend bringing into forefront the improvements brought across by the operational improvements through better practices (Gaurav Shard and Namratha Swamy 2014). While financing trade, FBs' principal focus is on promoting bilateral trade by offering finance at various stages of foreign trade cycle like product development, production, and marketing, import-export credit at pre-shipment and post-shipment stages, investment abroad and import of technology. FBs operate a wide range of lending programs. Financial packages related to foreign trade offered by the FBs are competitive and multi-currency. During the financial year 2003-04 to 2012-13 most of the FBs have met target for lending to export sector set by RBI under priority sector lending (12 per cent of Adjusted Net Bank Credit (ANBC) or Credit Equivalent Amount Off-Balance Sheet Exposure (CEOBSE).

Table 2.12.1Year wise Financing by Foreign Banks (FB) - figures in INR Million

\begin{tabular}{|l|l|l|l|l|l|}
\hline Year & $\begin{array}{l}\text { No. of } \\
\text { FB }\end{array}$ & Business & Advances & Investment & Foreign Trade \\
\hline $2003-04$ & 29 & 126490 & 713120 & 406850 & 6524750 \\
\hline $2004-05$ & 29 & 128530 & 852010 & 422450 & 8764050 \\
\hline $2005-06$ & 29 & 166630 & 936520 & 504140 & 11168270 \\
\hline $2006-07$ & 32 & 249680 & 1263390 & 714710 & 14122850 \\
\hline $2007-08$ & 32 & 350370 & 1619590 & 990920 & 16681760 \\
\hline $2008-09$ & 32 & 452110 & 1654150 & 1303530 & 22151910 \\
\hline $2009-10$ & 40 & 363430 & 1632600 & 1592910 & 22092700 \\
\hline $2010-11$ & 40 & 395160 & 1955110 & 1654990 & 28263890 \\
\hline $2011-12$ & 40 & 468930 & 2298490 & 2004880 & 38114220 \\
\hline $2012-13$ & 43 & 534600 & 2636800 & 2280630 & 43034810 \\
\hline
\end{tabular}

Source: - https://www.rbi.org.in/Scripts/Publications.aspx?publication=Annual

Table 2.12.1 indicates that during the period 2003-04 to 2012-13, with increase in business, advances and investment of FFIs, there is an increase in foreign trade of India.

Over the time foreign banks have operated in India, they have built a good team and created business processes adjusted to India's practices. While developing their niche market, slowly but steadily FBs are increasing their presence in India. FBs are, in general focusing on companies holding foreign capital with registration under Indian Companies Act-1956 as well as pure Indian companies which are engaged with bilateral trade with home and host country. FBs in India continue efforts to attract new clients, especially among foreign companies newly registered in India. The host and home country currency-denominated operations could become an important area for FBs in India in the near future. The first step on the way to expanding the use of the national currency as an international payment medium has already been made, many FBs are now allowed to work with home country currency and make payments from India in favor of companies from the home country. With the application of user friendly models FBs are highly competitive so far as quality of customer service and quick decision making are considered. Thus, it is significant to study the role of FBs in India's foreign trade and their application of models leading to their survival in India with grace. 
Table 2.12.2 Sector Wise Financing by Foreign Banks (FB) (Values in INR Million)

\begin{tabular}{|l|l|l|l|l|}
\hline Year & MSE (1) & $\begin{array}{l}\text { Exports } \\
(2)\end{array}$ & $\begin{array}{l}\text { Other } \\
\text { Sectors }\end{array}$ & Total \\
\hline $2012-13$ & 283000 & 612000 & 1380906 & 2275906 \\
\hline $2011-12$ & 217000 & 586000 & 1176991 & 1979991 \\
\hline $2010-11$ & 215010 & 424870 & 1081124 & 1721004 \\
\hline $2009-10$ & 211470 & 333960 & 881132 & 1426562 \\
\hline $2008-09$ & 180630 & 315110 & 939572 & 1435312 \\
\hline $2007-08$ & 154890 & 289540 & 921045 & 1365475 \\
\hline $2006-07$ & 116370 & 207110 & 717411 & 1040891 \\
\hline $2005-06$ & 84300 & 173260 & 527640 & 785,200 \\
\hline $2004-05$ & 69070 & 123390 & 433620 & 626,080 \\
\hline $2003-04$ & 53070 & 97600 & 365150 & 515,820 \\
\hline
\end{tabular}

Source:https://www.rbi.org.in/Scripts/Publications.aspx?publication=Annual

Table 2.12.2 shows that quantum of financing by FBs to sectors like MSE, Exports and other sectors, has an increasing trend.

FBs are developing their Indian business along with increasing their client base and implementing potential opportunities for massive entry into the market. Most of the FBs have the greatest experience in working with private depositors, and also lending actively to the real and various business sectors. FBs desire to enter the Indian market is understandable. Bilateral trade with various countries has been growing rapidly as economies are recovering from the global financial crisis. India's Foreign Trade climbed to a value of US\$ 800 billion over the last decade from US\$ 50 billion. Along with the basic target of profitability, FBs presence in India has helped the host and home country to increase Foreign Trade volume by availing the necessary financial services. It is highly significant to relate FBs presence in India with application of specific models and steady rise in India's Foreign Trade during the last decade.

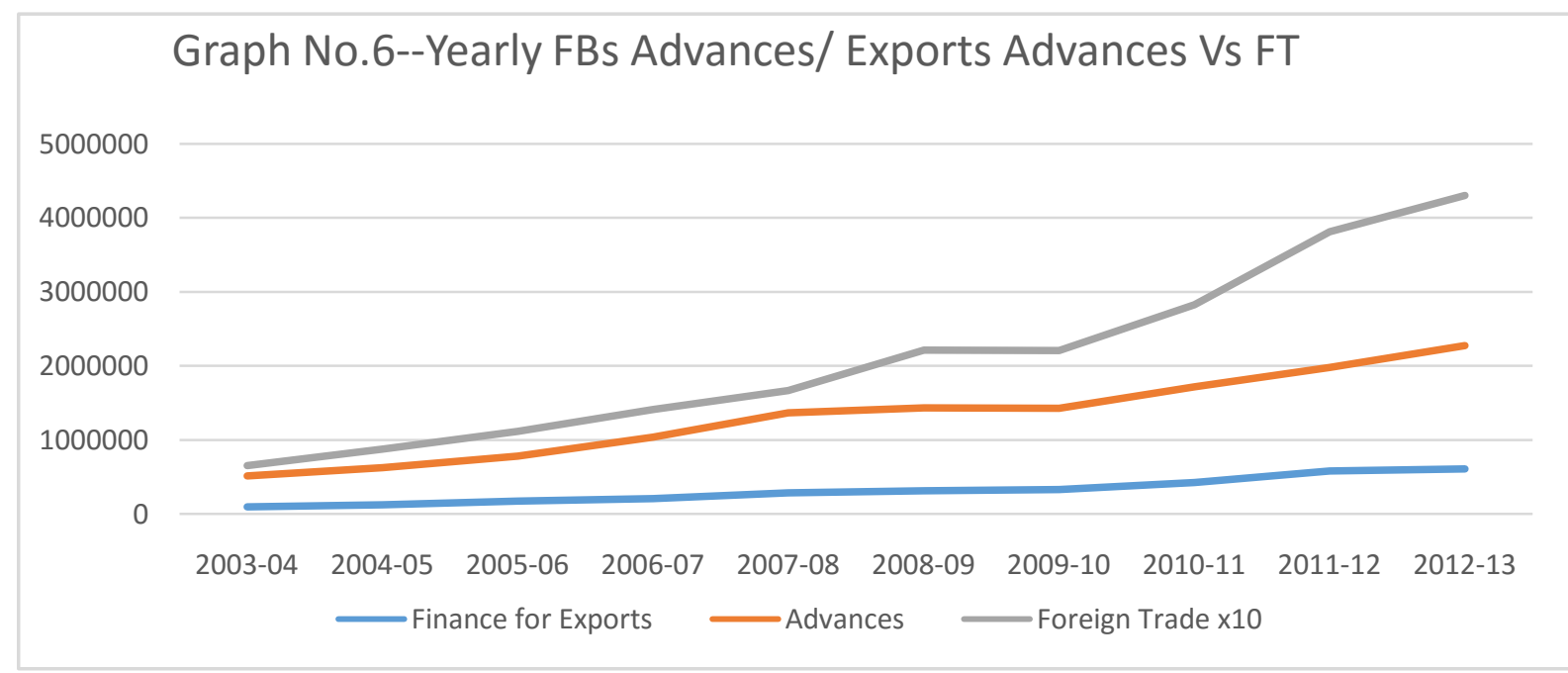


2.12.1 RBI Road MAP-2005 FOR Foreign Banks (FBs): - Before 2005, that is partially the deregulation wave pushed by RBI, foreign banks operating in India were highly dependent on the specific region they were operating in and clients as approved by RBI. Only high local demand for domestic and foreign trade financial services could fuel the limited growth of local financial institutions. Adding to that, strict RBI regulations largely prevented profiting through economies of scale. Only when, after 2005 RBI's Road Map for FBs, which allowed fair competition and geographical expansion, were implemented, to some extent, FBs became aware of new strategic possibilities. Now, FBs were free to enter new markets either by acquiring existing competitor bank franchises or by opening one of their own set up as per Wholly-Owned Subsidiary (WOS) model proposed by RBI. Furthermore, FBs holding companies were finally able to create a system of branch offices by consolidating previously independent affiliates. Waves of acquisitions and takeovers followed radically, which changed the structure of FBs. Newly grown FBs learned to exploit their size and, as a result, decrease marginal costs, having the ability to reduce service prices offered them a substantial competitive advantage. Additionally, to expansion in scale, FBs holding companies heavily invested in non-traditional financial services. Insurance and merchant financing company and acquisitions were another logical step towards expanding the scope of FBs' business. FBs holding institutions combined experience and knowledge gained in manufacturing, domestic trade financing and foreign trade financing and by using it quickly adapted to insurance and merchant financing businesses. For FBs risk assessments became more accurate and available for affiliates, decreasing service costs in newly acquired lines of financing business. From tables and graph it is observed that with an increase in advances given by FBs there is an increase in foreign trade-Exports and Imports

3 Understanding trends in India's Foreign Trade:-In the last decade, trade with the rest of the world has been buoyant, registering robust growth. While value of trade has increased considerably, the composition of trade basket remains little changed and direction of trade has registered some shifts during the observation period..

We first look at the export-side of India's trade, followed by the import-side in detail and the Key Findings are as under:-

\subsection{Exports: -}

3.1.1 India's exports recorded growth of $21.3 \%$ (CAGR) during the observation period

3.1.2 Manufactured goods account for major share of exports (61.2\% in FY13), followed by petroleum and crude products (20.1\% in FY13) and agri-products (13.5\% in FY13).

Contribution of petroleum and crude products in India's export basket has risen over the years, while that of manufactured goods has declined. Other commodity groups have registered range-bound changes in share.

3.1.3 Asia has always dominated as India's exports-partner over the years; followed by Europe, America and Africa. However, exports to America and Africa have declined during the observation period and increased with Asia instead.

3.1.4 Agri- and allied products have registered high growth of 22.2\% (CAGR, FY03-FY13) and stood at US $\$ 40.6$ billion in FY13. Major agri- and allied commodities exported by India include basmati rice, marine products, meat and meat products, oil meals, spices, wheat and sugar.

3.1.5 At US $\$ 183.6$ billion in FY13, manufactured goods have registered growth of $18.4 \%$ (CAGR, FY03-FY13).Major manufactured goods, exported by India include engineering goods, chemicals and related products, textiles and ready-made garments.

3.1.6 The export of ores and minerals has grown by 12.1\% (CAGR, FY03-FY13), to touch USD 5.6 billion in FY13, while export of petroleum and crude products has registered exponential growth of 41.9\% (CAGR, FY03-FY13) to stand at US\$ 60.2 billion in FY13.

3.1.7 In terms of share in overall exports, the share of agri- and allied products, ores and minerals and other commodities has moved in a range-bound fashion. However, there has been some perceptible shift from the manufactured goods to the petroleum and crude products segment between FY03 and FY13. It is interesting to note that, together manufactured goods and petroleum and crude products have accounted for $81.2 \%$ of overall exports in FY03 and FY13. However, the share of manufactured goods has dropped from $76.3 \%$ in FY03 to $61.2 \%$ in FY13, which in turn has been taken over by petroleum and crude products. Share of petroleum and crude products has risen considerably, from 
$4.9 \%$ in FY03 to $20.1 \%$ in FY13. While overall exports have increased by 5.7 times during this period, this has been enabled by petro products that have increased by 23.3 times followed by transport equipment by 13.8 times and electronics by 6.4 times. Chemicals were also important increasing by a similar rate as the aggregate.

3.1.8 Direction of Exports:-Asia is the largest export partner for India. There is a 23.0\% growth in exports to Asia. During the period 2003 to 2013, exports to Asia increased from US\$ 22.2 to US\$ 150.4 billion followed by America (US\$ 53.4 billion). It is observed that there is a more increase in exports to Asia zone compared to exports to US \& Europe zone (from $42.2 \%$ in 2003 to $50.1 \%$ in 2013). This is on account of moderation in economic activity in countries like US \& Europe zone resulting contraction in import demand coupled with increased trade integration of India with Asian countries yielding more import demand from Asian countries.

\subsection{Imports -}

3.2.1 During the period 2003 to 2013 there is a substantial increase in import demand of India being a growing economy. Except the year 2009-10 and 20010-11 there is always increase in India's import demand. India's imports in 2003 were US\$ 61.4 billion whereas in 2013 India's imports were US\$ 490.3 billion. There is growth of $26 \%$ (CAGR) during this period.

3.2.2 In 2003 imports of petroleum, oil and lubricants accounted for $34.5 \%$ and other items accounted for $65.5 \%$

3.2.3 It is observed that during the period 2003 to 2013, there is no significant change in import source. Asian countries are principal import sources followed by Europe and USA. There is fall in imports from Europe zone whereas there is an increase in imports from Asian countries and USA.

3.2.4 Imports of petroleum, oil and lubricants has grown at 28.5\% (CAGR, FY03-FY13), from USD 17.6 billion in FY03 to USD 169.0 billion in FY13.

4.2.5 Other items have grown by $24.8 \%$ during this period, to stand at USD 321.3 billion in FY13.

3.2.7 The contribution of other items in imports has been large (40.6\% in FY03 and 38.0\% in FY13). This comprises major import items such as gold and silver, coal, pearls and semi-precious stones, metal ferrous ores and metal scraps and electronic goods.

3.2.8 The other major contribution in imports is capital goods imports which has been a little decrease at $13.1 \%$ in FY03 and $12.3 \%$ in FY13.

3.2.9 For the food and related items segment, imports are focused in pulses and vegetable oil imports. The contribution of both food items and textile items remains at a low level in the country's overall import figure. In FY13 gold was the principal most important distinct import product, followed by electronics, non-electrical machinery, pearls, coal etc., metals etc. and chemicals. Gold has registered a very sharp increase in total imports from $6.3 \%$ to $10.9 \%$, resulting into a troubleshooting area for EXIM policy formulators and has necessitated a strict monitoring action this year.

3.2.10 Direction of Imports: - India's 57.7\% of overall imports are sourced from Asian countries amounting to US\$283.0 billion, with a growth of $26.0 \%$ (CAGR). This is mainly because of POL items. Next largest import source for India is Europe amounting to US\$ 91.7 billion, followed by America amounting to US\$ 58.2 billion. There is a increase in imports from Asia during the period 2003 to 2013 from 27\% to $57.7 \%$. Today Asia is the largest import source for India.

\section{Conclusion}

4.1 At present, Asia is the largest foreign trade partner of India with substantial increase in trade flows during the last decade. Manufactured goods plus petro related products have replaced primary agri products in the foreign trade quantum.

4.2 The increased refining capacity of India resulted in decrease in the contribution of manufacturing goods in India's foreign trade composition. Also explosion of information technology has led to a substantial increase in exports of service products.

4.3 Today, Asia has become prime source for Indian imports related various products. This is on account of large imports from China and imports of POL products from area specifically gulf countries. 


\section{References: -}

1 DGCIS's Report-2013

2 DGFT Report-2013

3 Dalal Street Investment Journal dated 25/5/2012

4 Edwards (1992) "Trade orientation, distortions and growth in developing countries," Journal of Development Economics, Elsevier, vol. 39(1), pages 31-57, July.

5 Gaurav Shard and Namratha Swamy 2014 "Impact of Foreign Banks on the Indian Economy" IIM Bangalore WORKING PAPER NO: 451

6 Harrison (1996) "Openness and Growth: A Time-Series, Cross-Country

Analysis for Developing Countries", Journal of Development Economics, 48,

$419-447$.

7 Ministry of Commerce \& Industries Report 2013

8 RBI Annual Publication 2003-04 to 2012-13

9 The Economic Survey 2014-15

10 WTO's World Trade Report, 2014 